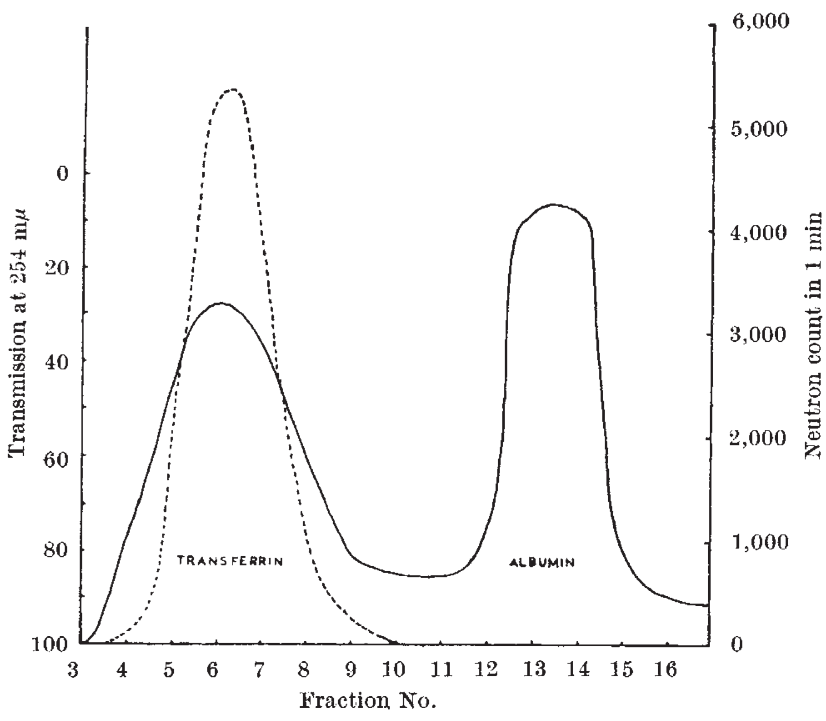

Fig. 1. Chromatography of the transferrin/albumin fraction on a colum of DEAE-'Sephadex A-50'. Elution was started with 0.1 M 2-amino 2-hydroxymethylpropane $1: 3$ diol (tris) and its hydrochloride in $0 \cdot 1 \mathrm{M}$ sodium chloride, $p \mathrm{H} 8.0$, followed by a gradient of $0.1 \mathrm{M}-2.0 \mathrm{M} \mathrm{NaCl}$ in $0 \cdot 1 \mathrm{M}$ tris-HCl. The fraction volumes werc about $3.5 \mathrm{ml}$. - Transmission; - - . , radioactivity

'Sephadex G-200' gel-filtration. Resolution of the albumin/ transferrin fraction into its components by DEAE'Sephadex $A-50$ ' and subsequent delayed neutron counting showed plutonium to be present in the transferrin fraction only as depicted in Fig. 1. Additionally the protein fractions were characteriz acetate strips, using veronal buffer at $p H$ 8.6 and staining with Ponceau $S$ (ref. 5). Autoradiography of the unstained electrophoresis strips demonstrated that the plutonium migrates at the same rate as the transferrin.

G. BoOCOCK

D. S. POPPLEWELA.

Atomic Weapons Research Establishment, Aldermaston, Berkshire.

Hunts, J. A., and Barron, E. S. G., U.S. Atomie Energy Comm. Rep. M.D.D.C. 1268, Argonne National ĹLaboratory (1947)

${ }^{2}$ Beliayev, Yu. A., Meditsinkaya Radiologiya, 4, 45 (1959); in English, $U, S$, Atomic Energy Comm. Rep. AEC-tr-3878, Argonne National Laboratory (1959).

${ }^{3}$ Gelotte, B., Flodin, P., and Killander, J., Arch. Biochem. Biophys., Supp. 1, 319 (1962)

4 Amiel, S., Anal. Chem., 34, 1683 (1962).

"Snith, I., in Chromatographic and Electrophoretic Techniques, 56 (William Heinemann Medical Books, Ltd., London, 1960).

\section{Far-infra-red Spectra of some Square-planar lons}

THERE are three different assignments of the infra-redactive modes of $\mathrm{K}_{2} \mathrm{PtCl}_{4}$ in the literature ${ }^{1-3}$. One was based on a low-resolution spectrum ${ }^{1}$ and is thus mis. leading. The other two authors differed in their assignment of $v_{2}$ and $v_{7}$, but their data are in good agreement except that Mathieu et al. ${ }^{3}$ reported a band at $160 \mathrm{~cm}^{-1}$ which was not found by either Sacconi et al. ${ }^{2}$ or by ourselves. We have observed the spectrum of $\mathrm{K}_{2} \mathrm{PtCl}_{4}$ to $40 \mathrm{~cm}^{-1}$ and support Sacconi's results and assignment for the following reasons.

(1) The site symmetry of $\left[\mathrm{PtCl}_{4}\right]^{2-}$ in the potassium salt is the same as that of the freo ion. It is thus difficult to account for the triplet nature attributed to $v_{2}$ by Mathieu et al. (2) The band near $110 \mathrm{~cm}^{-1}$ assigned by Mathieu et al. to $v_{2}$ is absent in the spectrum of Magnus's green salt, and can be assigned to a translational lattice mode of the potassium ions, three of which should be infra-red-active. Wo find additional lattice modes at 87.5 and $59 \mathrm{~cm}^{-1}$, which may also be associated with the potassium ions.

We have made the first observations of $\nu_{2}$ and $\nu_{7}$ for $\mathrm{K}_{2} \mathrm{PdX}_{4}(X=\mathrm{Cl}$ and $\mathrm{Br})$, of $\nu_{6}$ for $\mathrm{KAuI}_{4}$, and of the complete far-infra-red spectra of $\left[M\left(\mathrm{NH}_{3}\right)_{4}\right] \quad\left[M^{\prime} \mathrm{Cl}_{4}\right]$ $\left[M, M^{\prime}=\mathrm{Pd}, \mathrm{Pt}\right]$. Our assignments for the complex ions in these compounds are supported by the band width considerations: those bands assigned to $a_{2 u}$ modes are sharp and narrow, while those assigned to $e_{u}$ modes are at least twice as broad. A similar band width effect is seen in $\nu(\mathrm{CO})$ bands for complexes of the type $M(\mathrm{CO})_{3}$ $(\pi$-arene)

Table 1. INFRA-RED-ACTIVE FREQUENCIES $\left(\mathrm{CM}^{-1}\right)$ OF SOME SQJARE-PLANAR

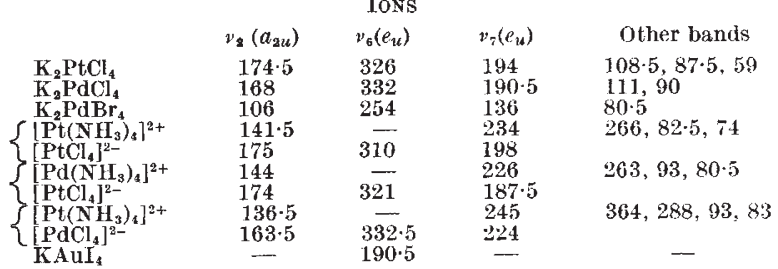

All the ions in the complexes $\left[M\left(\mathrm{NH}_{3}\right)_{4}\right]\left[M^{\prime} \mathrm{Cl}_{4}\right]$ have site symmetry $\mathrm{C}_{4}$. There should not therefore be any splitting of existing degeneracies, but the Raman-active $v_{1}$ in the free ions should become infra-red-active. We have not observed it, but we do find a weak-medium band at $266 \mathrm{~cm}^{-1}\left(M=M^{\prime}=\mathrm{Pt}\right), 263 \mathrm{~cm}^{-1}\left(M=\mathrm{Pd}, M^{\prime}=\mathrm{Pt}\right)$ or $288 \mathrm{~cm}^{-1}\left(M=\mathrm{Pt}, M^{\prime}=\mathrm{Pd}\right)$. This is very low for $v_{1}$ for any of the complex ions and we tentatively assign it to a combination of $\nu_{7}$ of the ammine complex ions with a lattice mode. There is no evidence that the metal-metal interaction in Magnus's green salt has any significant offect on the infra-red spectra of the complex ions, as compared with $\mathrm{K}_{2} \mathrm{PtCl}_{4}$ and $\left[\mathrm{Pt}\left(\mathrm{NH}_{3}\right)_{4}\right] \mathrm{Cl}_{2}$. In particular, the $a_{2 u}$ out-of-plane deformation bands of $\left[\mathrm{PtCl}_{4}\right]^{2-}$ are constant in both frequency and intensity.

D. M. Adains

D. M. MORRIS

Department of Chemistry,

University of Leicester.

Adams, D. M., and Gebbie, H. A., Spectrochim. Acta, 19, 925 (1963)

2 Sabatini, A., Sacconi, L., and Schettino, V., Inorg. Chem., 3, 1775 (1964).

${ }^{3}$ Poulet, H., Delorme, P., and Mathieu, J. P., Spectrochim. Acta, 20, 1855 $(1964)$.

\section{Methane-rich Perchloric Acid Flames}

THe study of flames supported by the vapour of 72 per cent perchloric acid ${ }^{1,2}$ has been continued by an investigation into methane-rich premixed flames of perchloric acid. Perchloric acid flames have already been shown to have no effective lower flammability limit since a decomposition flame of the acid vapour alone can be stabilized $^{2}$. It has now been found that mixtures containing up to at least 84 per cent methane in perchloric acid are flammable; this corresponds to 20 times as much methane as in a stoichiometric mixture, whereas methaneoxygen mixtures are only flammable up to 61 per cent methane ${ }^{3}$, corresponding to $3 \cdot 1$ times as much methane as in a stoichiometric mixture.

The methane-perchloric acid flames were stabilized on cylindrical 'Pyrex' burners of internal diameter of $1 \cdot 13-$ $25.4 \mathrm{~mm}$ surrounded by a $65 \mathrm{~mm}$ jacket tube so that the flames were burning in an atmosphere of argon. The apparatus was preheated to $210^{\circ} \mathrm{C}$ by nichrome heating wire in order to maintain the perchloric acid in the vapour phase. All the flames were at atmospheric pressure.

Burning velocitios, temperatures and burnt gas compositions were measured for flames containing $2 \cdots 18$ times as much methane as is required for a stoichiometric mixture. No carbon formation, as revealed by luminous yellow streaks or zones, was found with any of these flames. Burnt gas concentrations for methane, hydrogen, carbon monoxide, carbon dioxide and water in molecules per 100 molecules of initial methane are presented as a function of the mixture ratio, $\lambda$, in Fig. 1 (the diluent 